\title{
SEGURITIES REGULATION: RULE 10b-5 PROVIDES A BASIS FOR STOCKBROKER'S SUIT AGAINST A DEFRAUDING PURGHASER
}
A case of first impression, $A . T$. Brod \& Co. $v$. Perlow ${ }^{1}$ allowed a broker to assert a federal cause of action against a defrauding stock purchaser under section $10(\mathrm{~b})$ of the Securities Exchange Act of $1934^{2}$ and rule 10b-5.3 A. T. Brod \& Co., stockbrokers, alleged that Jack and Adele Perlow placed orders for several securities listed and traded on the New York Stock Exchange, fraudulently intending to pay for those shares only if their market price increased before payment was due. When the price of the shares declined and pay- ment was not forthcoming, Brod sold the securities at a loss and sought to recover damages in a suit predicated upon the Perlows' alleged violation of rule $10 \mathrm{~b}-5$. The district court dismissed Brod's complaint, concluding that Brod was not an investor, and that no fraud involving the investment value of the security nor any fraud usually associated with securities transactions had been alleged. Finding the district court's construction of $10(\mathrm{~b})$ and $10 \mathrm{~b}-5$ "too narrow," the Court of Appeals for the Second Circuit reversed.4
Section 10 (b), the "catch-all" clause of the Exchange Act," authorizes the Securities and Exchange Commission to prescribe such rules and regulations to combat manipulative or deceptive devices and contrivances "as [are] necessary or appropriate in the public interest or for the protection of investors." 6 Under the authority of this section, the SEG promulgated rule $10 \mathrm{~b}-5$, which, subject to express jurisdictional conditions, renders unlawful all fraudulent schemes in connection with the purchase or sale of securi- ties. Since Kardon v. National Gypsum Co., ${ }^{7}$ the courts have in-

\footnotetext{
1375 F.2d 393 (2d Cir. 1967).

248 Stat. 891 (1934), 15 U.S.C. $\$ 78 j$ (b) (1964).

s 17 C.F.R. $\$ 240.106-5$ (1964, Supp. 1966).

375 F.2d at 396.

- See Hearings on Stock Exchange Regulation Before the House Commitee on Inter.

- 48 Stat. 891 (1934), 15 U.S.C. $\$ 78$ j (b) (1964).

769 F. Supp. 512 (E.D. Pa. 1946).
} state and Foreign Commerce, 73d Cong., 2d Sess. 115 (1934) (testimony of Mr. Thomas G. Corcoran) quoted in Ruder, Givil Liability Under 10b-5: Judicial Revision of Legis- lative Intent?, 57 Nw. U.L. REv. 627, 658 (1963); S. REP. No. 792, 73d Cong., 2d Sess. 18 (1934). See also Fratt v. Robinson, 203 F.2d 627, 631 (9th Cir. 1953). 
ferred civil liability for violations of the rule and have construed rule $10 \mathrm{~b}-5$ to impose few restrictions on the defrauded claimant. Recovery has not been limited to transactions within the organized securities markets. ${ }^{8}$ Further, the rejection of privity as a prerequisite to an actionable claim $^{9}$ and the existence of diminutive scienter ${ }^{10}$ and, in some jurisdictions, reliance ${ }^{11}$ requirements have increased the availability of the remedy. At present, the only substantial impediment to civil relief under $10 \mathrm{~b}-5$ is a notion that the litigant must be a "defrauded purchaser or seller"12 but even this stricture has been latitudinately construed.13

Accounting for the virtual absence of hobbling construction is a continuing assault on narrow definition of the rule by those anxious to gain the advantages ${ }^{14}$ of litigating securities fraud claims in the federal courts. The terse language of rule $10 \mathrm{~b}-5$ has induced confining judicial interpretations, but with the exception of the purchaser/seller limitation all have been overruled or distinguished. Thus, neither the availability of a common law remedy in the state courts $^{15}$ nor the possibility of a more restricted remedy under another

${ }^{8}$ Ellis v. Carter, 291 F.2d 270 (9th Cir. 1961); Fratt v. Robinson, 203 F.2d 627 (9th Cir. 1953); H. L. Green Co. v. Childree, 185 F. Supp. 95 (S.D.N.Y. 1960).

- Miller v. Bargain City, U.S.A., Inc., 229 F. Supp. 33, 37 (E.D. Pa. 1964); see Cooper v. North Jersey Trust Co., 226 F. Supp. 972, 978 (S.D.N.Y. 1964); Comment, 74 YALE L.J. 658 (1965). But see Joseph v. Farnsworth Radio \& Television Corp., 99 F. Supp. 701 (S.D.N.Y. 1951), aff'd, 198 F.2d 883 (2d Cir. 1952); Meisel v. North Jersey Trust Co., 218 F. Supp. 274 (S.D.N.Y. 1963); Donovan v. Taylor, 136 F. Supp. 552 (N.D. Cal. 1955).

${ }^{10}$ Ellis v. Carter, 291 F.2d 270, 274 (9th Cir. 1961); Texas Continental Life Ins. Co. v. Bankers Bond Co., 187 F. Supp. 14 (W.D. Ky. 1960), rev'd on other grounds sub. nom. Texas Continental Life Ins. Co. v. Dunne, 307 F.2d 242 (6th Cir. 1962); see O'Neill v. Maytag, 339 F.2d 764, 767-68 (2d Cir. 1964); Note, 63 Mrch. L. REv. 1070 (1965). But see Weber v. C.M.P. Corp., 242, F. Supp. 321 (S.D.N.Y. 1965); Trussell v. United Underwriters, Ltd., 228 F. Supp. 757 (D. Colo. 1964). Cf. Dack v. Shanman, 227 F. Supp. 26 (S.D.N.Y. 1964).

12 See, e.g., Speed v. Transamerica Corp., 99 F. Supp. 808 (D. Del. 1951); Ruder, supra note 5 , at 678 .

12 Birnbaum v. Newport Steel Corp., 193 F.2d 461, 463 (2d Cir.), cert. denied, 343 U.S. 956 (1952). See also Joseph v. Farnsworth Radio \& Television Corp., 198 F.2d 883, 887 (2d Cir. 1952) (Frank, J., dissenting) (10b-5 not limited to common law fraud).

18 See, e.g., Vine v. Beneficial Finance Co., 374 F.2d 627 (2d Cir. 1967), 1967 DukE L.J. 898; Hooper v. Mountain States Sec. Corp., 282 F.2d 195, 202-03 (5th Cir. 1960), cert. denied, 365 U.S. 814 (1961).

14 See 3 Loss, Securities Regulation 1763-97 (2d ed. 1961); Latty, The Aggrieved Buyer or Seller or Holder of Shares in a Close Corporation Under the S.E.C. Statutes, 18 Law \& Contemp. Рrob. 505, 525-34 (1953); Comment, Private Remedies Available under Rule 10b-5, 20 Sw. L.J. 620 (1966).

${ }^{16}$ Compare Beury v. Beury, 127 F. Supp. 786, 789-90 (S.D.W. Va. 1954), disapproved, 222 F.2d 464 (4th Cir. 1955), with Connelly v. Balkwill, 174 F. Supp. 49, 56 (N.D. Ohio 1959), aff'd, 279 F.2d 685 (6th Cir. 1960). 
provision of the securities law will presently bar a $10 \mathrm{~b}-5$ complaint.10 Likewise, privity between vendor and purchaser, once thought requisite, appears to be no longer demanded.17 Brod, too, involves the interment of judicial gloss, for the district court dismissed Brod's complaint upon the strength of dictum in Birnbaum v. Newport Steel Corp. ${ }^{18}$

In Birnbaum, the Second Circuit construed 10b-5 as "directed solely at that type of misrepresentation or fraudulent practice usually associated with the sale or purchase of securities ...."10 Specifically rejecting this dictum, as well as the district court's related holdings that a $10 \mathrm{~b}-5$ plaintiff must be an investor and the fraud be alleged as to the investment value of the security, the Second Circuit in Brod held that section $10(\mathrm{~b})$ and rule $10 \mathrm{~b}-5$ prohibit all fraudulent schemes in connection with the sale or purchase of securities, even "garden type" varieties of fraud. ${ }^{20}$ Emphasizing the language of the provisions, rather than judicial precedent and legislative history, the court observed that neither the statute nor the rule explicitly limit the proscribed conduct to fraud involving investors or the investment value of the securities. To have inferred such qualifications from the language of the provisions would have offended the remedial purposes deemed inherent in the securities laws by the Supreme Court. ${ }^{21}$ Thus, dismissal was improper, for Brod's complaint met all the requirements of a 10b-5 action: the practices allegedly employed by the Perlows were fraudulent; the fraud was committed "in connection with the purchase or sale of [a] security";22 and the fraud had been perpetrated by means of a facility of a national securities exchange. ${ }^{23}$

The Second Circuit stretched no definitions to find federal jurisdiction in Brod. Neither the cases nor the legislative history support the narrow construction given $10 \mathrm{~b}-5$ by the district court. The ascendant purpose of the Exchange Act was to assure the integrity of

\footnotetext{
${ }^{10}$ Compare Montague v. Electronic Corp. of America, 76 F. Supp. 933 (S.D.N.Y. 1948), with Fischman v. Raytheon Mfg. Co., 188 F.2d 783 (2d Cir. 1951).

${ }^{17}$ See note 9 supra and accompanying text.

18193 F.2d 461 (2d Cir.), cert. denied, 343 U.S. 956 (1952).

${ }^{10} 193$ F.2d at 464 .

20375 F.2d at 397.

21375 F.2d at 396, citing SEC v. Capital Gains Research Bureau, Inc., 375 U.S. 180,

195 (1963). See also J. I. Case Co. v. Borak, 377 U.S. 426, 433-34 (1964).

2277 C.F.R. $\$ 240.10 \mathrm{~b}-5$ (1964, Supp. 1966).

23375 F.2d at 397.
} 
the securities marketing process, ${ }^{24}$ and toward that end rule $10 \mathrm{~b}-5$ was issued. ${ }^{25}$ Though many claimants under the rule have been investors, ${ }^{26}$ and the fraud has often involved the investment value of the stock, ${ }^{27}$ those elements have not been prerequisite to a $10 \mathrm{~b}-5$ claim. ${ }^{28}$ Accordingly, such interpretive limitations were properly rejected by the Brod court. Significant, too, in Brod is the recognition of a civil remedy coextensive with the injunctive power of the SEC. The very existence of a private right under the securities laws has been predicated at least in part on the self-enforcing qualities which civil liability imparts to a statute. ${ }^{29}$ If a private right is to be created which will effectively promote the ends of the statute, illegal conduct subject to SEC injunction should also be the basis of a civil action. The Brod court tacitly indicated that the private right encompasses the injunctive jurisdiction of the SEC, for Judge Kaufman premised his finding that the Perlows' alleged conduct was fraudulent upon prior cases in which the SEC procured injunctions against similar conduct. ${ }^{30}$

\footnotetext{
24 See Hooper v. Mountain States Sec. Corp., 282 F.2d 195, 202 (5th Cir. 1960), cert. denied, 365 U.S. 814 (1961); Fratt v. Robinson, 203 F.2d 627, 631 (9th Cir. 1953); Securities Exchange Act of 1934, § 2, 48 Stat. 881, 15 U.S.C. $\$ 78 b$ (1964).

${ }^{25}$ See Birnbaum v. Newport Steel Corp., 193 F.2d 461, 463 (2d Gir.), cert. denied, 343 U.S. 956 (1952).

${ }^{20}$ See, e.g., Matheson v. Armbrust, 284 F.2d 670 (9th Cir. 1960), cert. denied, 365 U.S. 870 (1961); Pfeffer v. Cressaty, 223 F. Supp. 756 (S.D.N.Y. 1963).

${ }^{37}$ See, e.g., List v. Fashion Park, Inc., 222 F. Supp. 798 (S.D.N.Y. 1963); Speed v. Transamerica Corp., 99 F. Supp. 808 (D. Del. 1951).

${ }^{28}$ See, e.g., Hooper v. Mountain States Sec. Corp., 282 F.2d 195, 202 (5th Gir. 1960), cert. denied, 365 U.S. 814 (1961) (investor status not required); Glickman v. Schweickart \& Co., 242 F. Supp. 670, 673-74 (S.D.N.Y. 1965) (misrepresentation need not involve the security itself); Cooper v. North Jersey Trust Co., 226 F. Supp. 972, 978 (S.D.N.Y. 1964) (10b-5 not limited to fraud in exchange of consideration); $M$. L. Lee \& Co. v. American Cardboard \& Packaging Corp., 36 F.R.D. 27 (E.D. Pa. 1964) (claimant not investor; alleged fraud neither in security's value, nor fraud "usually associated with" securities transactions).

20 See J. I. Case Co. v. Borak, 377 U.S. 426, 432 (1964).

${ }^{80} 375$ F.2d at 397, citing, e.g., SEC v. DuBory, Civ. No. 1614, D. Mass., Oct. 6, 1966; SEC v. Greenwald, Civ. No. 60-1022, S.D.N.Y., Jan. 18, 1963.
} 